\title{
Imigração e colonização: conflitos pela terra no Paraná e São Paulo entre os séculos XIX e XX
}

\author{
Ângelo Priori e João Fábio Bertonha (org.) \\ Guarapuava (PR), Editora da UNICENTRO, 2015, 225 p.
}

O estudo das migrações nos centros universitários de diversas regiões de nosso país tem a possibilidade de oferecer novos olhares para fatos relevantes sobre a história das migrações e a atualidade da mobilidade humana. Num país continental como o Brasil, a migração tem diversas facetas, cujos contornos particulares devem-se à história regional e sua inserção no processo de formação sócio-econômica nacional. Nesse sentido, resgatar a história das migrações por regiões, como é o caso dos estados de São Paulo e Paraná e, em particular, a articulação entre projetos de colonização, fluxos migratórios e disputa pela terra, tem importância fundamental para conhecer as dinâmicas sociais e econômicas que configuraram tanto essa região como sua inserção no restante do país.

Parece ser esse o horizonte do livro, que reúne uma coletânea de artigos provindos de estudos de jovens pesquisadores de diferentes níveis, de estudantes da graduação a doutorandos, que freqüentam o Programa de Pós-Graduação em Política e Movimentos Sociais da Universidade Estadual de Maringá (UEM). São estudos diferentes, mas que procuram de alguma maneira ter em comum os temas da migração e da ocupação do território, abordando desde a ação das empresas de colonização até a nova configuração territorial da fronteira do país, em Nova Iguaçu. Segundo a proposta da introdução, trata-se de "fenômenos que são estudados, muitas vezes, de forma estanque, mas que, na verdade, formam os dois lados da mesma moeda". Na verdade, apesar da intenção dos organizadores, explícita na apresentação de um processo social em comum, cada texto tem uma metodologia e perspectiva teórica que lhe é própria, não havendo uma unidade mais consistente no livro como um todo.

O livro se divide em duas grandes partes: "As companhias colonizadoras e a ocupação do território: São Paulo e Paraná" e "Imigrantes, migrantes e a ocupação dos espaços paulista e paranaense". Assim, apesar do título do livro destacar a relação entre migração, ação das colonizadoras e conflito agrário, é apenas na primeira parte que se pode perceber a força da imbricação desses fatores. Nos três textos que compõe essa parte se ressalta de maneira desigual a importância da arregimentação de trabalhadores migrantes e suas famílias na lógica de ocupação, valorização e comercialização de terras pelas empresas 
colonizadoras. O primeiro texto, "A Companhia de Agricultura, Imigração e Colonização (Caic) e o processo imigratório no Estado de São Paulo (1928-1936)", é um trabalho cuidadoso de leitura dos registros e relatórios da Companhia de Agricultura, Imigração e Colonização do Estado de São Paulo (Caic), o qual demonstra como a atração e arregimentação de famílias imigrantes na Europa estava ligada à disponibilização de terras para colonização na região Oeste do Estado de São Paulo. No entanto, não se sabe se esses projetos se realizaram na prática ou não, ou quais foram as vicissitudes enfrentadas pela Companhia em sua trajetória. Subentende-se que essa teria tido um desempenho abaixo do esperado, mas não se tem comprovação disso. E, sobretudo, o texto não faz relação entre o processo de especulação da terra e a criação de condições para conflitos agrários.

Os outros dois textos dessa primeira parte buscam analisar, justamente, a ação de colonizadoras e o desenvolvimento de conflitos agrários no Oeste do Paraná e no Paraguai. O segundo deles, "A construção das Memórias sobre os conflitos agrários na região Oeste do Paraná (1950/80)", trata sobre os conflitos entre a empresa Colonizadora Norte do Paraná e os diversos e sucessivos grupos de colonos que migravam para o Oeste do Paraná em busca de terras, nas décadas de 1950 a 80 . A partir de fontes indiretas, diversas e desiguais (jornais, teses e estudos anteriores), busca explicitar as visões distintas e conflitantes entre os dirigentes da empresa, de um lado, e posseiros e arrendatários, de outro, sobre o processo violento de titulação, destituição e ocupação das terras. A violência da história de ocupação do território também fica em evidência no terceiro estudo dessa parte do livro, "A luta dos 'brasiguaios' pelo acesso à terra", que procura resgatar o processo de ocupação da região oriental do Paraguai por migrantes brasileiros. $O$ autor expõe a relação contraditória entre a política de ocupação do território pelas empresas de colonização no Paraguai e a ação das redes de solidariedade dos imigrantes. Também aqui o desenvolvimento do texto se serve basicamente de fontes indiretas, também desiguais entre si, para recontar a luta pelo acesso a terra dos conhecidos "brasiguaios". Em ambos os textos, mais do que um processo de análise dos fatores que relacionam a ação das colonizadoras e o uso dos fluxos de migrantes, o que se propõem é uma denúncia da lógica de violência institucionalizada na ocupação do território e de valorização das terras, explicitada nos conflitos agrários.

A segunda parte do trabalho muda completamente de tom e de objeto de análise. Os textos colocam toda sua atenção no processo de inserção de gerações de imigrantes nessa região, com um acento em suas práticas culturais. Principalmente nos dois primeiros textos da segunda parte, o que está em questão é a relação entre cultura e etnia do imigrante e sua inserção no território. O primeiro texto, "Os imigrantes de origem alemã no Paraná: debate sobre a presença teuta no Estado", apoiando-se fortemente numa bibliografia já existente sobre a história da imigração e colonização alemã no Brasil, sobretudo 
no século XIX, procura evidenciar a força dos vínculos étnicos e comunitários na descrição das chamadas "colônias alemãs". Também se preocupa com a discussão teórica sobre emprego da categoria "aculturação". O centro da atenção é a ocupação de territórios no entorno de Curitiba, muito embora o autor se utilize sem muita distinção da ocupação do Paraná e da região da capital do Estado como referências. Esse trabalho não problematiza a ação de colonização do território e a questão agrária, e não avança além de informações históricas gerais. O texto seguinte, "A imigração espanhola para São Paulo e as memórias de Braz Ponce Martins (1897-1938)", se apoia nas memórias de um descendente de imigrantes espanhóis, para discorrer sobre sua infância e história familiar, apenas mencionando, sem, contudo, problematizá-las, as relações entre colonização, presença de colonos imigrantes e questão agrária. A autora opta por enveredar na discussão do problema da assimilação ou não do imigrante espanhol no Brasil, e as evidências da preservação de alguns de seus costumes. O seu interesse maior está na relevância do uso da memória oral como fonte de pesquisa, a fim de resgatar a história do cotidiano, no caso, da ocupação do interior do Estado de São Paulo, e depois, do Paraná, por uma família de origem espanhola. Apenas no final do texto, entretanto, o objeto de análise aparece, isto é, os trechos da memória desse imigrante, em poucas páginas, mas não chegam a ser analisados em profundidade.

O último texto dessa parte, "A ocupação do espaço brasileiro da Tríplice Fronteira", é o mais curto do livro. Ele faz referência ao que seria um quadro interessante para uma possível pesquisa sobre a história de ocupação da fronteira paranaense do país e sua atual configuração étnica e econômica, no contexto da globalização do capital. $O$ artigo destaca a particularidade da ocupação desse território, desde o período colonial, como Colônia Militar, e o papel da colonização por imigrantes de origem européia na década de 1940. O texto menciona, sem aprofundar, as difíceis relações entre a população remanescente de indígenas expropriados, os cultivadores de erva mate e os ocupantes descendentes de imigrantes, antes de entrar na transformação dessa região no grande enclave comercial de Foz de Iguaçu, Ciudad Del Est e Puerto Iguazu, a partir do fim dos anos 1960. A estruturação dessa zona franca ensejou a vinda de outros fluxos migratórios, de origem internacional, dando uma nova configuração urbana a esse território. Enfim, o texto é curto, e não lança nenhuma análise sobre esse quadro, mas acena para uma problemática nova: as novas relações conflitivas entre ocupação do território e presença de imigrantes, e (por que não?) sua relação com as questões agrárias ainda vivas na fronteira entre Brasil e Paraguai.

Esse livro revela o esforço de um centro universitário regional em mostrar seu trabalho em torno de um complexo de questões sociais e históricas relevantes para o país. São estudos de alguma maneira incipientes, com bastante discussão teórica e pouco embasamento empírico realmente novo. Aos que já conhecem a bibliografia usada, parece algo envelhecido. Porém, na medida em que puder 
acessar fontes diretas sobre as questões levantadas e, sobretudo, fizer um enlace articulando as várias questões e cenários tratados, poderá dar uma contribuição importante para a compreensão da emergência dos vários e entrelaçados fluxos nessa macrorregião. Como aponta o último artigo, poderia até mesmo levantar um quadro mais aprofundado da realidade migratória local, nesse complexo fronteiriço, no âmbito das relações socioeconômicas globais.

Sidnei Marco Dornelas, cs Assessor da Comissão Episcopal para a Ação Missionária e Cooperação Intereclesial - CNBB Grupo de Apoio do Setor Mobilidade Humana - CNBB 